\title{
Biogeochemical cycling of urea in the aquatic systems of Pindaré and Turiaçu River basins, a pre-Amazonian floodplain, Baixada Maranhense, Brazil
}

Ciclo biogeoquímico da ureia nos sistemas aquáticos das bacias hidrográficas do Pindaré e Turiaçu, várzea pré-Amazônica, Baixada Maranhense, Brasil

Osamu Mitamura ${ }^{1}$, Nobutada Nakamoto ${ }^{2}$, Maria do Socorro Rodrigues Ibañez ${ }^{3}$, Paulo Roberto Saraiva Cavalcante ${ }^{4}$, José Policarpo Costa Neto ${ }^{4}$ and Ricardo Barbieri ${ }^{4}$

${ }^{1}$ School of Environmental Sciences, University of Shiga Prefecture, Hikone, Shiga 522-0057, Japan e-mail: mitamura@ses.usp.ac.jp

${ }^{2}$ Department of Applied Sciences, Shinshu University, Ueda, Nagano 386-8567, Japan e-mail: cwscnkmt@ybb.ne.jp

${ }^{3}$ Departamento de Ecologia, Universidade de Brasília - UnB, Campus Darcy Ribeiro, Asa Norte, CEP 70910-900, Brasília, DF, Brazil

e-mail: marias@unb.br

${ }^{4}$ Departamento de Oceanografia e Limnologia, Universidade Federal do Maranhão - UFMA, Campus do Bacanga, CEP 65085-580, São Luís, MA, Brazil e-mail: prcavalcante@yahoo.com.br; policarpolab@yahoo.com.br

\begin{abstract}
Aim: This work is aimed at extending the understanding of urea cycle in freshwater ecosystems. Its degradation rate concerning microorganisms activities was measured in the turbid waters of Pindaré and Turiaçu rivers located on the pre-Amazonian floodplain, Brazil; Methods: The Pindaré and Turiaçu aquatic systems have distinct dry and rainy periods. The investigation was developed in the middle of the rainy period, and field activities were carried out in the extensive water bodies from the middle to lower reaches. The rate of degradation in the surface waters of the two aquatic systems was determined with in situ simulation technique using ${ }^{14} \mathrm{C}$-labelled urea. Photosynthetic rates were determined by the radiocarbon technique simultaneously with experimental measurements of urea degradation rate; Results: Urea degradation rates (sum of carbon incorporation into particulate matter and $\mathrm{CO}_{2}$ liberation into water) were $2.0 \mathrm{mg}$ urea $\mathrm{C} \mathrm{m}^{-3}$ day $^{-1}$ in the Pindaré and $17.1 \mathrm{mg}^{2}$ urea $\mathrm{C} \mathrm{m}^{-3}$ day $^{-1}$ in the Turiaçu waters. Daylight values were obviously higher than those in the dark, and the urea degradation rates in Turiaçu showed much higher values than those in Pindaré. Most of the urea degradation occurred during the $\mathrm{CO}_{2}$ liberation phase. The average of chlorophyll $a$ specific urea degradation rate was 0.13 and $0.83 \mathrm{mg}$ urea $\mathrm{C} \mathrm{mg} \mathrm{chl.} a^{-1}$ day ${ }^{-1}$ in both river waters. The ratio of urea carbon degradation to photosynthetic carbon assimilation in both waters averaged 1.2 and $4.2 \%$, respectively. The residence time of urea in the surface water was calculated as 2.3 to 4.5 days in the Pindaré and 0.21 to 0.50 days in the Turiaçu. Much shorter residence times were obtained in the Turiaçu due to the high degradation rate of urea; Conclusion: The correlation coefficient between the urea degradation rate and chlorophyll $a$ or photosynthetic rate showed a statistically significant value in the Turiaçu. This indicates that in the Turiaçu system the urea degradation rate was proportional to the standing crop of phytoplankton and their photosynthetic rate. A strong relationship between the urea carbon incorporation rate and photosynthetic rate in the light bottles was observed, indicating that the carbon incorporation into the phytoplankton cells was also related to the photosynthetic rate. The present brief residence time indicates that the urea was being rapidly recycled in the euphotic zone of the investigated systems in the rainy period.
\end{abstract}

Keywords: urea degradation, phytoplankton, pre-amazonian floodplain.

Resumo: Objetivo: $\mathrm{O}$ objetivo deste trabalho é ampliar o conhecimento do ciclo da ureia em ecossistemas de água doce. A taxa de sua degradação em relação às atividades dos microorganismos foi medida nas águas turvas dos rios Pindaré e Turiaçu localizados na várzea pré-Amazônica, Baixada Maranhense, Brasil; Métodos: Os sistemas aquáticos dos rios Pindaré e Turiaçu têm períodos diferentes de chuva e seca. A investigação foi realizada no meio do período chuvoso, e as atividades de campo foram feitas ao longo dos extensos 
corpos d'água compreendendo águas de médio a baixo cursos. A taxa de degradação nas águas superficiais nas respectivas estaçóes de ambos os sistemas foi determinada com a técnica de simulação in situ usando ${ }^{14} \mathrm{C}$ - ureia. As taxas fotossintéticas foram determinadas pela técnica de radio carbono simultaneamente com medidas experimentais de degradação; Resultados: As taxas de degradação (somatório da incorporação de carbono na matéria particulada e liberação de $\mathrm{CO}_{2}$ na água) foram 2,0 $\mathrm{mg}$ de ureia $\mathrm{C} \mathrm{m}^{-3} \mathrm{dia}^{-1}$ nas águas do Pindaré e $17,1 \mathrm{mg}$ ureia $\mathrm{C} \mathrm{m}^{-3} \mathrm{dia}^{-1}$ nas do Turiaçu. Os valores no claro foram naturalmente maiores que os obtidos no escuro, e as taxas de degradação no Turiaçu foram muito mais elevadas que as do Pindaré. A maior parte da degradação ocorreu durante a fase de liberação de $\mathrm{CO}_{2}$. As taxas de degradação específica de ureia da clorofila $a$ foram calculadas com valor médio de 0,13 e $0,83 \mathrm{mg}$ ureia $\mathrm{C} \mathrm{mg}$ chl. $a^{-1} \mathrm{dia}^{-1}$ nas águas de ambos os rios. As taxas de degradação de ureia carbono para a assimilação fotossintética de carbono em ambas as águas foram em média 1,2 e 4,2\%, respectivamente. O tempo de residência desse composto orgânico na superfície da água foi entre 2,3 a 4,5 dias no Pindaré e 0,21 a 0,50 dias no Turiaçu. Tempos de residência muito mais curtos foram achados nas águas do Turiaçu devido à elevada taxa de degradaçáo; Conclusáo: $\mathrm{O}$ coeficiente de correlaçáo entre a taxa de degradação da ureia e a clorofila $a$ ou a taxa fotossintética foi calculada como um valor estatisticamente significativo nas águas do Turiaçu. Isto indica que no sistema Turiaçu a taxa de degradaçáo desse nutriente foi proporcional à quantidade de fitoplâncton e sua taxa fotossintética. Foi observada uma sólida relação entre a taxa de incorporaçáo de ureia carbono e a taxa de fotossíntese nas garrafas no claro, indicando que a incorporação de carbono no fitoplâncton está relacionada com a taxa fotossintética. O breve tempo de residência indica que a ureia estava sendo rapidamente reciclada na zona eufótica dos sistemas investigados no período chuvoso.

Palavras- chave: degradação da ureia, fitoplâncton, várzea pré-amazônica.

\section{Introduction}

Amazon River ecosystem has been thoroughly researched (Fisher and Parsley, 1979; Sioli, 1984; Forsberg et al., 1988; Fisher et al., 1988; Marlier, 1967; Melack and Fisher, 1990; Richey et al., 1990; Devol et al., 1995; Junk and Weber, 1996; Ibañez, 1997; Bozelli and Garrido, 2000; Carneiro et al., 2002; Farjalla et al., 2002; Roland et al., 2002; Guenther and Bozull, 2004). Freshwater bodies in this floodplain provide high levels of productivity, which are sustained by various biogeochemical cycles. There are also data from lentic waters in the Baixada Maranhense published by Reid and Turner (1988), Barbieri et al. (1989) and Ibañez et al. (2000).

Urea is one of the important nitrogen sources for phytoplankton (Eppley et al., 1971; McCarthy, 1972; Harvey and Caperon, 1976; Kristiansen, 1983; Harrison et al., 1985; Mitamura and Saijo, 1986a; Price and Harrison, 1988; Chang et al., 1995; Presing et al., 2001; Twomey et al., 2005) and plays a significant role in the nitrogen cycle (Mitamura and Saijo, 1986b; Mitamura et al., 2006) of freshwater lakes and oceans. The degradation of urea by phytoplankton has been demonstrated using ${ }^{14} \mathrm{C}$-labelled urea to elucidate the metabolism of nitrogenous compounds in freshwater lakes (Carpenter et al., 1972a; Remsen et al., 1972; Webb and Haas, 1976; Mitamura, 1986; Mitamura and Saijo, 1986a; Mitamura et al., 1994, 2000). Urea is presumably degraded more effectively by phytoplankton than by bacteria, although ureadegrading bacteria are extensively distributed in natural waters (ZoBell and Feltham, 1935; Taga, 1972; Satoh and Hanya, 1976; Cho and Azam, 1995; Cho et al., 1996).

Some data are available on urea degradation for lacustrine ecosystems. In the euphotic zone of freshwaters, urea degradation is associated with the photosynthesis of phytoplankton (Mitamura and Saijo, 1986a; Mitamura et al., 2000). Several investigators have reported using ${ }^{15} \mathrm{~N}$-labelled urea that it plays a significant role as a nitrogen source for phytoplankton growth (Mitamura and Saijo, 1986a, 1986b; Gu et al., 1997; Presing et al., 2001; Mitamura et al., 2006). Mitamura and Saijo (1986a) suggested that urea is mainly degraded during the urea nitrogen uptake by phytoplankton, and that the urea carbon is assimilated simultaneously by phytoplankton as one of their carbon sources.

Knowledge of urea degradation and its cycling in diversified tropical freshwater bodies is quite limited. The current investigations were carried out in a typical pre-Amazonian floodplain ecosystem, the Baixada Maranhense, Maranhão, Brazil, located in the southern part of the Amazon River estuary. Our aim is to understand the urea cycle in a freshwater 
ecosystem by measuring its rate degradation in relation to the activities of microorganisms in the Turiaçu and Pindaré aquatic systems, which differ in salinity and turbidity.

\section{Material and Methods}

\subsection{Investigation area}

Baixada Maranhense is an Environmental Protection Area (APA in Brazil), with an area of almost $18,000 \mathrm{~km}^{2}\left(2^{\circ} 00^{\prime}-4^{\circ} 00^{\prime} \mathrm{S}\right.$ and $44^{\circ} 20^{\prime}$ $\left.45^{\circ} 30^{\prime} \mathrm{W}\right)$ and distinct dry and rainy seasons. This wetland area is subject to a seasonal flooding cycle with medium-scale river water level fluctuations (4-6 meters). During our investigation the Pindaré and Turiaçu aquatic systems were in the middle of the rainy period. Water levels, therefore, were consequently considered low. Field investigations were carried out of extensive water bodies located in the middle to lower reaches of the Pindare and Turiaçu Rivers in March 1998 (Figure 1).
Urea degradation rate in surface waters was measured at five stations (Sta.1; $2^{\circ} 17.72^{\prime} \mathrm{S}$ and $45^{\circ}$ 22.98' W, water depth of $2.6 \mathrm{~m}$, Sta.2; $2^{\circ} 18.66^{\prime} \mathrm{S}$ and $45^{\circ} 22.74^{\prime} \mathrm{W}, 3.5 \mathrm{~m}$, Sta.3; $2^{\circ} 18.96^{\prime} \mathrm{S}$ and $45^{\circ} 20.59^{\prime} \mathrm{W}, 2.5 \mathrm{~m}$, Sta.4; $2^{\circ} 17.13^{\prime} \mathrm{S}$ and $45^{\circ} 20.08^{\prime} \mathrm{W}, 3.4 \mathrm{~m}$, Sta.5; $2^{\circ} 15.83^{\prime} \mathrm{S}$ and $45^{\circ}$ $\left.19.40^{\prime} \mathrm{W}, 4.7 \mathrm{~m}\right)$ of the Turiaçu River, and at seven (Sta.1; $3^{\circ} 19.52^{\prime} \mathrm{S}$ and $45^{\circ} 00.36^{\prime} \mathrm{W}, 9.0 \mathrm{~m}$, Sta.2; $3^{\circ} 19.31^{\prime} \mathrm{S}$ and $45^{\circ} 01.00^{\prime}$ W, $5.5 \mathrm{~m}$, Sta.3; $3^{\circ} 13.69^{\prime} \mathrm{S}$ and $45^{\circ} 00.95^{\circ} \mathrm{W}, 1.8 \mathrm{~m}$, Sta.4; $3^{\circ}$ $13.51^{\prime} \mathrm{S}$ and $44^{\circ} 59.99^{\prime} \mathrm{W}, 1.5 \mathrm{~m}, \mathrm{Sta} .53^{\circ} 15.83^{\prime} \mathrm{S}$ and $44^{\circ} 59.74^{\prime} \mathrm{W}, 1.5 \mathrm{~m}$, Sta.6; $3^{\circ} 14.61^{\prime} \mathrm{S}$ and $45^{\circ} 01.70^{\prime} \mathrm{W}, 1.4 \mathrm{~m}$, Sta.7; $3^{\circ} 14.15^{\prime} \mathrm{S}$ and $45^{\circ}$ 03.49' W, $1.5 \mathrm{~m}$ ) of the Pindaré River aquatic systems, respectively. The present investigation stations were lentic in character, exhibiting the geomorphometric property of a shallow lake located at the middle-lower reaches of both aquatic systems.

\subsection{Procedure of chemical analyses}

Water temperature, $\mathrm{pH}$ and electric conductivity were measured in the field using a boat equipped

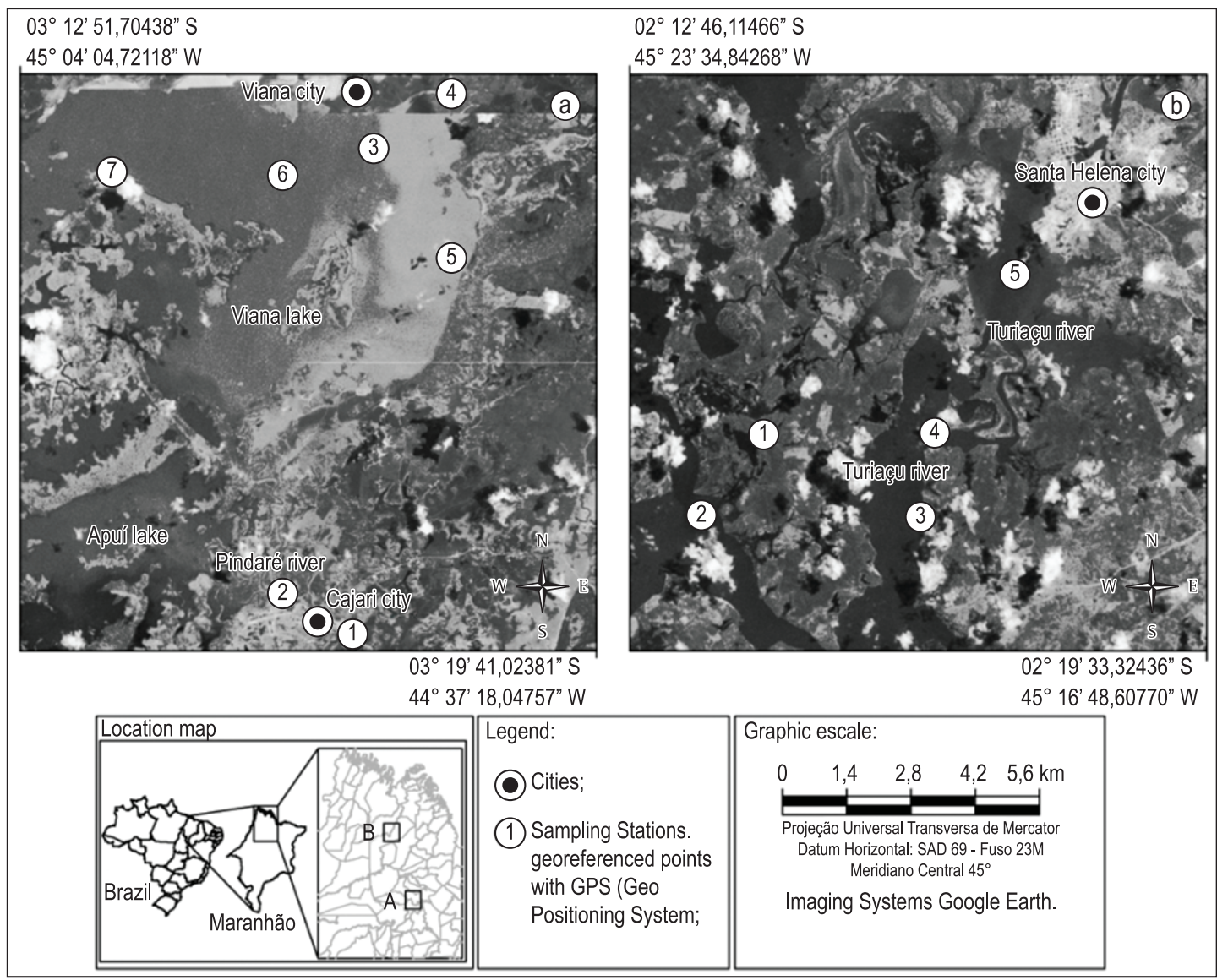

Figure 1. Map showing the investigation areas in the Pindaré and Turiaçu river basins, Baixada Maranhense, Maranhão, Brazil. 
with a water quality monitoring system (YSI, model 33). Measurements of transparency were taken with a Secchi disk. Electric conductivity was equated to the value at $25^{\circ} \mathrm{C}$. Water samples (approximately $0.2 \mathrm{~m}$ depth) were collected at the respective stations with a plastic pail. These samples were used for turbidity measurements in the laboratory using a Turbidmeter (Hach, $2100 \mathrm{~N}$ ). After filtration with a $0.2 \mu \mathrm{m}$ membrane filter, the concentrations of six major elements $\left(\mathrm{Na}, \mathrm{K}, \mathrm{Mg}, \mathrm{Ca}, \mathrm{Cl}, \mathrm{SO}_{4}\right)$ were determined with an Ion Chromatograph (Dionex, DX-120).

For the determination of biogeochemical constituents and chlorophyll $a$ concentrations, the waters were immediately filtered through glass fiber filters (Whatman GF/F) purged of organic matter by ignition at $420^{\circ} \mathrm{C}$. Both the filters and filtrates were then frozen solid at $-20{ }^{\circ} \mathrm{C}$ until chemical analyses in the laboratory. Urea concentration was determined by Newell et al. method (1967). Ammonia was determined by Sagi method (1966); nitrite after Bendschneider and Robinson (1952), nitrate after Mitamura (1997), and phosphate (DIP) after Murphy and Riley (1962). Dissolved organic carbon (DOC) and nitrogen (DON) were determined with an infra-red Total Organic Carbon Analyzer (Shimadzu, TOC-5000A) and an Automatic Total Nitrogen Analyzer (Yanaco TN301P), respectively. Chlorophyll $a$ was determined with a fluorometer (Turner Designs, 10-AU) according to Holm-Hansen et al. (1965). Particulate organic carbon and nitrogen were determined with a CHN Corder (Yanaco, MT-5) after the samples were free of carbonate carbon using $1 \mathrm{M} \mathrm{HCl}$ solution.

\subsection{Measurement of urea degradation and photosynthesis}

For measuring urea degradation rates, $20 \mathrm{~mL}$ of water samples were taken from the surface layer in the two respective aquatic systems and, after, this volume was placed into three series of clear plastic bottles. Crystalline ${ }^{14} \mathrm{C}$ labeled

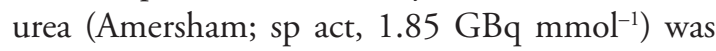
dissolved in sterile, deionized distilled water, and the ${ }^{14} \mathrm{C}$ labeled urea stock solution was then stored at $-20{ }^{\circ} \mathrm{C}$. After adding $0.5 \mathrm{~mL}$ of the diluted ${ }^{14} \mathrm{C}$ labeled urea solution (containing 1.0 nmole ${ }^{12} \mathrm{C}$ urea and $1.85 \mathrm{kBq}{ }^{14} \mathrm{C}$ urea) into each bottle, $0.2 \mathrm{~mL}$ of concentrated formaldehyde solution was immediately added to the series of control bottles. The second series of bottles was wrapped in a black sheet for determination of the urea degradation rate in the dark regime. The series of transparent and dark bottles were incubated in a water tank which was placed in the field. Incubation temperature was similar to that of the sampling stations. After incubating the bottles during the period of sunlight, the biological activity was stopped by adding formaldehyde solution. The weather condition on the respective incubation days was pallid sky. The sample water in each bottle was then filtered through a $0.2 \mu \mathrm{m}$ Nuclepore filter. The filter was put in a scintillation vial, and $10 \mathrm{~mL}$ of Bray scintillation fluid (Bray, 1960) was added. The radioactivity was then measured with a liquid scintillation spectrometer (Aloka LSC-651) to determine the rate of urea carbon incorporation into the particulate matter. The filtrate of each sample was poured into a separate $50 \mathrm{~mL}$ glass bottle with a screw cap, and a $\mathrm{CO}_{2}$ absorption tube containing $0.5 \mathrm{~mL}$ of n-ethanolamine was inserted into each bottle to absorb the ${ }^{14} \mathrm{CO}_{2}$ liberated from the water sample solution by acidification. After adding $0.5 \mathrm{~mL}$ of $1 \mathrm{M}$ sulfuric acid solution to each filtrate, the bottles were then sealed tightly and left for four days at room temperature. After adding the scintillation fluid to n-ethanolamine containing ${ }^{14} \mathrm{CO}_{2}$ liberated from the water sample in the bottle, the radioactivity was determined as described above.

Photosynthetic rates were measured by Steemann Nielsen's radiocarbon technique (1952) simultaneously with the experimental measurements of the urea degradation rate. The water samples were poured into both light and dark bottles and inoculated with ${ }^{14} \mathrm{C}$ bicarbonate solution to a final concentration of $185 \mathrm{kBq} \mathrm{L}{ }^{-1}$. Thereafter, measurements of the photosynthetic rates were conducted using the same procedure as that for the urea carbon incorporation rate as described above. The concentration of total carbon dioxide in the water sample was determined with an infrared carbon dioxide analyzer (Horiba VIA-510), as described by Satake et al. (1972).

\section{Results and Discussion}

\subsection{General features}

There were no appreciable differences in the vertical distribution of the physico-chemical variables determined at the respective investigation stations, indicating that water column was well mixed vertically.

Water temperature ranged from 27.4 to $31.6^{\circ} \mathrm{C}$ and $\mathrm{pH}$ exhibited a weak acidic property. Electric conductivity revealed a considerable difference 
between the two aquatic systems, ranging from

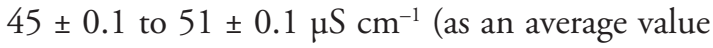
with standard deviation) in the Turiaçu and $22 \pm 3$ to $28 \pm 1 \mu \mathrm{S} \mathrm{cm} \mathrm{cm}^{-1}$ in the Pindaré (Table 1). In the Pindaré high salinity of $144 \pm 6 \mathrm{mg} \mathrm{L}^{-1}$ was calculated as estimated from the sum of the six major ionic elements $\left(\mathrm{Na}^{+}, \mathrm{K}^{+}, \mathrm{Mg}^{2+}, \mathrm{Ca}^{2+}, \mathrm{Cl}^{-}\right.$, $\mathrm{SO}_{4}^{2-}$, while in the Turiaçu salinity presented a fairly low value of $26 \pm 1 \mathrm{mg} \mathrm{L}{ }^{-1}$. The major ionic constituents $\left(\mathrm{Na}^{+}, \mathrm{K}^{+}, \mathrm{Mg}^{2+}, \mathrm{Ca}^{2+}, \mathrm{Cl}^{-}, \mathrm{SO}_{4}^{2-}\right)$ in waters of the present aquatic systems showed a variation depending on the type of chemicals. Transparency measured with a Secchi disk was 0.1 to $0.2 \mathrm{~m}$ in the Pindare and 0.4 to $0.5 \mathrm{~m}$ in the Turiaçu. Turbidity ranged from $82 \pm 5$ to $107 \pm 6$ NTU and $19 \pm 3$ to $23 \pm 2$ NTU in the Pindaré and the Turiaçu systems, respectively.

\subsection{Distribution of urea and biogeochemical components}

Urea concentrations and other biogeochemical variables in the surface waters at respective stations in the Pindaré and Turiaçu aquatic systems were listed in Table 1. Urea concentrations ranged from $0.36 \pm 0.17$ to $0.66 \pm 0.09 \mu \mathrm{M}$, as an average with standard deviation (average $5.9 \mu \mathrm{g} \mathrm{C} \mathrm{\textrm {L } ^ { - 1 }}$ as urea carbon and $13.7 \mu \mathrm{g} \mathrm{N} \mathrm{L}^{-1}$ as urea nitrogen) in the
Pindaré, and $0.30 \pm 0.08$ to $0.64 \pm 0.11 \mu \mathrm{M}(5.5 \mu \mathrm{g}$ $\mathrm{C} \mathrm{L}^{-1}$ and $12.8 \mu \mathrm{g} \mathrm{N} \mathrm{L}^{-1}$ ) in the Turiaçu. The urea concentration displayed no appreciable change among stations in either of the aquatic systems. Total nitrogenous nutrient (TNN; sum of urea, ammonia, nitrite and nitrate nitrogen) amounted to $68 \pm 11 \mu \mathrm{g} \mathrm{N} \mathrm{L} \mathrm{L}^{-1}$, as an average value with standard deviation, in the Pindaré, and $42 \pm 8 \mu \mathrm{g} \mathrm{N} \mathrm{L}{ }^{-1}$ in the Turiaçu. This indicates that in both aquatic systems these nitrogenous compounds were not mostly loaded from their watersheds and/or were rapidly consumed by microorganisms. The principal nitrogenous nutrients were ammonia and nitrate. An appreciable amount of urea nitrogen in the TNN was observed, ranging from 15 to $27 \%$ and 24 to $38 \%$ of TNN in both the Pindare and Turiaçu. In freshwater lakes, urea was found to make an appreciable contribution to the nitrogenous nutrients (Satoh et al., 1980; Mitamura and Saijo, 1981). The present concentrations of urea in the waters of the Pindaré and Turiaçu systems were comparable to those reported by the above investigators in oligotrophic to eutrophic waters (Mitamura et al., 1995; Saijo et al., 1997). The urea levels in the present aquatic systems seem to constitute the source of one of the essential

Table 1. Concentrations of urea and other biogeochemical parameters, and photosynthetic rates in the Pindaré and Turiaçu aquatic systems. The contributions of urea nitrogen to TNN (sum of urea, ammonia, nitrite and nitrate nitrogen) and to dissolved organic nitrogen (DON), and of urea carbon to dissolved organic carbon (DOC) are listed. Data is shown as an average value with its range in parenthesis.

\begin{tabular}{|c|c|c|}
\hline Parameter & Pindaré station & Turiaçu station \\
\hline Urea-N ( $\left.\mu g \mathrm{~N} \mathrm{~L}^{-1}\right)$ & $14(10-19)$ & $13(9-18)$ \\
\hline $\operatorname{TNN}\left(\mu g N^{-1}\right)$ & $68(51-84)$ & $42(32-54)$ \\
\hline $\mathrm{NH}_{4}^{+}-\mathrm{N}\left(\mu \mathrm{g} \mathrm{N} \mathrm{L}{ }^{-1}\right)$ & $25(13-43)$ & $13(8-17)$ \\
\hline $\mathrm{NO}_{2}^{-}-\mathrm{N}\left(\mu \mathrm{g} \mathrm{N} \mathrm{L}^{-1}\right)$ & $2.6(2.1-3.2)$ & $3.1(2.5-3.7)$ \\
\hline $\mathrm{NO}_{3}^{-}-\mathrm{N}\left(\mu \mathrm{g} \mathrm{N} \mathrm{L}{ }^{-1}\right)$ & $26(16-34)$ & $14(10-20)$ \\
\hline $\mathrm{DON}(\mu \mathrm{g} \mathrm{N} \mathrm{L-1})$ & $420(330-490)$ & $830(680-990)$ \\
\hline Urea-N/TNN (\%) & $20(15-27)$ & $30(24-38)$ \\
\hline Urea-N/DON (\%) & $3.4(2.4-5.5)$ & $1.5(1.0-1.8)$ \\
\hline Urea-C ( $\mu \mathrm{g} \mathrm{C} \mathrm{L-1})$ & $5.9(4.4-7.9)$ & $5.5(3.7-7.7)$ \\
\hline $\mathrm{DOC}(\mathrm{mg} \mathrm{C} \mathrm{L-1})$ & $4.0(3.6-4.4)$ & $6.8(6.3-7.2)$ \\
\hline Urea-C/DOC (\%) & $0.15(0.10-0.20)$ & $0.08(0.05-0.11)$ \\
\hline Phosphate-P ( $\left.\mu g \mathrm{P} \mathrm{L}^{-1}\right)$ & $3.6(2.7-4.3)$ & $0.9(0.6-1.2)$ \\
\hline Water temperature $\left({ }^{\circ} \mathrm{C}\right)$ & $29.7(27.4-31.1)$ & $31.0(30.5-31.61)$ \\
\hline Transparency (m) & $0.18(0.13-0.20)$ & $0.44(0.40-0.49)$ \\
\hline Electric conductivity $\left(\mathrm{mS} \mathrm{m}^{-1}\right)$ & $26(22-28)$ & $4.7(4.5-4.8)$ \\
\hline Salinity $\left(\mathrm{mg} \mathrm{L}^{-1}\right)$ & $140(130-150)$ & $26(25-28)$ \\
\hline Turbidity (NTU) & $94(82-110)$ & $21(19-23)$ \\
\hline $\mathrm{PC}\left(\mathrm{g} \mathrm{C} \mathrm{m}^{-3}\right)$ & $12.2(8.5-15.7)$ & $5.3(3.7-7.2)$ \\
\hline $\mathrm{PN}\left(\mathrm{mg} \mathrm{N} \mathrm{m}^{-3}\right)$ & $890(640-1210)$ & $640(540-810)$ \\
\hline Chlorophyll a (mg chl.a m-3) & $16(13-20)$ & $21(18-24)$ \\
\hline Photosynthesis (mg C m-3 $\mathrm{d}^{-1}$ ) & $171(105-233)$ & $404(325-505)$ \\
\hline
\end{tabular}


nitrogenous nutrients for phytoplankton growth in the euphotic zone of both aquatic systems.

Contributions of urea carbon to DOC averaged $0.15 \%$ in the Pindare and $0.08 \%$ in the Turiaçu waters, while the percentages of DON, on the other hand, were $3.4 \%$ and $1.5 \%$ in both waters. Mitamura and Saijo (1981) have reported that urea comprised, as an average value, $0.29 \%$ of DOC and $13.8 \%$ of DON in Lake Biwa. Mitamura and Hino (personal communication) have noted that the contributions of urea carbon or nitrogen were counted as 0.05 to $0.24 \%$ of DOC or 0.9 to $5.0 \%$ of DON, as an average percentages in each of four tropical lakes. The contributions in the present study were comparable in their values to those in tropical lakes but lower than those in Lake Biwa. Only a small amount of DOC was represented by urea. Thus, in the present aquatic systems, urea seems to furnish a rather insignificant contribution to the DOC and DON variations.

The DIP concentration in the waters was 1.9 to $5.7 \mu \mathrm{g} \mathrm{L} \mathrm{L}^{-1}$. Both nitrogen and phosphorus were the limiting nutrients for phytoplankton growth in the euphotic zone from the two systems as the data seem to indicate, regarding the nitrogen and phosphorus levels and their ratio compared with that of the Redfield stoichiometric ratio (Redfield, 1958).

\subsection{Photosynthetic activity and urea degradation rate}

Concentrations of $\mathrm{PC}$ and $\mathrm{PN}$ averaged $12 \mathrm{~g} \mathrm{Cm}^{-3}$ and $890 \mathrm{mgNm}^{-3}$ in the Pindare and $5.3 \mathrm{~g} \mathrm{C} \mathrm{m}^{-3}$ and $640 \mathrm{mg} \mathrm{Nm}^{-3}$ in the Turiaçu waters, respectively. Chlorophyll $a$ amounts were, respectively, $16 \pm 2 \mathrm{mg}$ chl. $a \mathrm{~m}^{-3}$ and $21 \pm 3 \mathrm{mg}$ chl. $a \mathrm{~m}^{-3}$ in the Pindaré and Turiaçu, showing a distribution similar to those of PC and PN. To compare the particulate matter characteristics between both aquatic systems, the ratio of PC concentration to turbidity or the chlorophyll $a$ amount was calculated. The organic carbon content and phytoplankton biomass in the particulate matter of the Pindaré system was quite low, with a low ratio of PC to turbidity and a high ratio of PC to chlorophyll $a$. The Turiaçu system, however, with their high ratio of $\mathrm{PC}$ to turbidity and low ratio of PC to chlorophyll $a$ was characterized as turbid water rich in phytoplanktonic particulate matter that might contain the fragments of macrophytes supplied by a dense macrophyte zone.

Photosynthetic rates, determined simultaneously during our urea degradation experiments, ranged from 163 to $233 \mathrm{mg} \mathrm{C} \mathrm{m}^{-3}$ day $^{-1}$ in the Pindaré and 335 to $505 \mathrm{mg} \mathrm{C} \mathrm{m}^{-3}$ day $^{-1}$ in the Turiaçu (Table 1). Photosynthetic activity (photosynthetic rate per unit amounts of chlorophyll $a$ during one day) was low, ranging from 8.1 to $12.4 \mathrm{mg}$ C mg chl. $a^{-1}$ day $^{-1}$ in the Pindaré and 16.7 to $21.9 \mathrm{mg} \mathrm{C} \mathrm{mg} \mathrm{chl.} a^{-1}$ day $^{-1}$ in the Turiaçu (Figure 2), with activity levels generally lower than those observed in natural clear lakes.

The distribution of urea degradation rates at respective stations in the Pindaré and Turiaçu aquatic systems are on Figure 2. The hourly rate of urea degradation (sum of hourly rates of carbon incorporation into particulate matter and $\mathrm{CO}_{2}$ liberation into water, originating in the urea carbon) during the incubations ranged from 0.08 to $0.13 \mathrm{mg}$ urea $\mathrm{C} \mathrm{m}^{-3} \mathrm{hr}^{-1}$ in the light bottle and 0.06 to $0.08 \mathrm{mg}$ urea $\mathrm{C} \mathrm{m}^{-3} \mathrm{hr}^{-1}$ in the dark one at the Pindaré stations, and from 0.68 to $1.16 \mathrm{mg} \mathrm{C} \mathrm{m}^{-3} \mathrm{hr}^{-1}$ and 0.42 to $0.68 \mathrm{mg} \mathrm{C} \mathrm{m}^{-3} \mathrm{hr}^{-1}$ in both bottles at the Turiaçu stations. The range of the daily rates of urea degradation in the surface water, estimated from the light and dark values, was 1.6 to $2.4 \mathrm{mg}$ urea $\mathrm{C} \mathrm{m}^{-3}$ day $^{-1}$ (average $2.0 \mathrm{mg}$ urea $\mathrm{C} \mathrm{m}^{-3}$ day $^{-1}$ ) in the Pindaré and 13.2 to $20.7 \mathrm{mg} \mathrm{C}$ $\mathrm{m}^{-3}$ day $^{-1}\left(16.3 \mathrm{mg} \mathrm{C} \mathrm{m}^{-3}\right.$ day $\left.^{-1}\right)$ in the Turiaçu. The rates of carbon incorporation and $\mathrm{CO}_{2}$ liberation phases in the urea degradation ranged from 0.17 to $0.32 \mathrm{mg} \mathrm{C} \mathrm{m}^{-3}$ day $^{-1}$ and 1.40 to $2.12 \mathrm{mg} \mathrm{C} \mathrm{m}^{-3}$ day $^{-1}$ in the Pindaré, and 3.1 to $5.6 \mathrm{mg} \mathrm{C} \mathrm{m}^{-3}$ day $^{-1}$ and 10.1 to $17.5 \mathrm{mg} \mathrm{C} \mathrm{m}^{-3}$ day $^{-1}$ in the Turiaçu stations, respectively. The urea degradation rates in the Turiaçu showed much higher values than the ones in the Pindaré.

Table 2 shows the contribution of the carbon incorporation phase to the urea degradation. 9 to $27 \%$ of daily urea degradation was incorporated into the particulate matter. The contributions in the Turiaçu stations were high, whereas the percentages at the Pindaré stations were low. Most of the urea degradation occurred during the phase of $\mathrm{CO}_{2}$ liberation, especially in the Pindaré waters. In the light incubations, an appreciable contribution occurred in the carbon incorporation phase, whereas the values in the dark incubations were almost negligible; there tended to be no differences in either of the aquatic systems. These percentages in light and dark bottles were in the same range as those in Brazilian tropical lakes (Mitamura et al., 1995) and in temperate lakes, rivers and oceans (e.g., Webb and Haas, 1976; Mitamura and Saijo, 1980, 1986a), but showed high values compared with those of Irmisch (1991) in coastal areas. 
The urea degradation rates were obviously higher in light than in dark regimes. The ratios from dark to light values for $\mathrm{CO}_{2}$ liberation rates revealed considerably high values, ranging from 0.62 to 0.97 in the Pindaré and 0.79 to 0.96 (as carbon ratio) in the Turiaçu, while reaching only negligible levels during the phase of carbon incorporation (Table 2). A similar tendency was reported in coastal waters by Tamminen and Irmisch (1996).

\subsection{Relationship between urea degradation and} phytoplankton photosynthesis

Specific urea degradation rates, using chlorophyll $a$ as a cell parameter, were calculated to range from 0.09 to $0.15 \mathrm{mg}$ urea $\mathrm{C} \mathrm{mg}$ chl. $a^{-1} \mathrm{day}^{-1}$ at the respective stations in the Pindaré, and from 0.68 to $0.96 \mathrm{mg}$ urea $\mathrm{C} \mathrm{mg} \mathrm{chl.} a^{-1}$ day $^{-1}$ in the Turiaçu (Figure 3). The specific rates in the Turiaçu waters were approximately ten times higher than those in
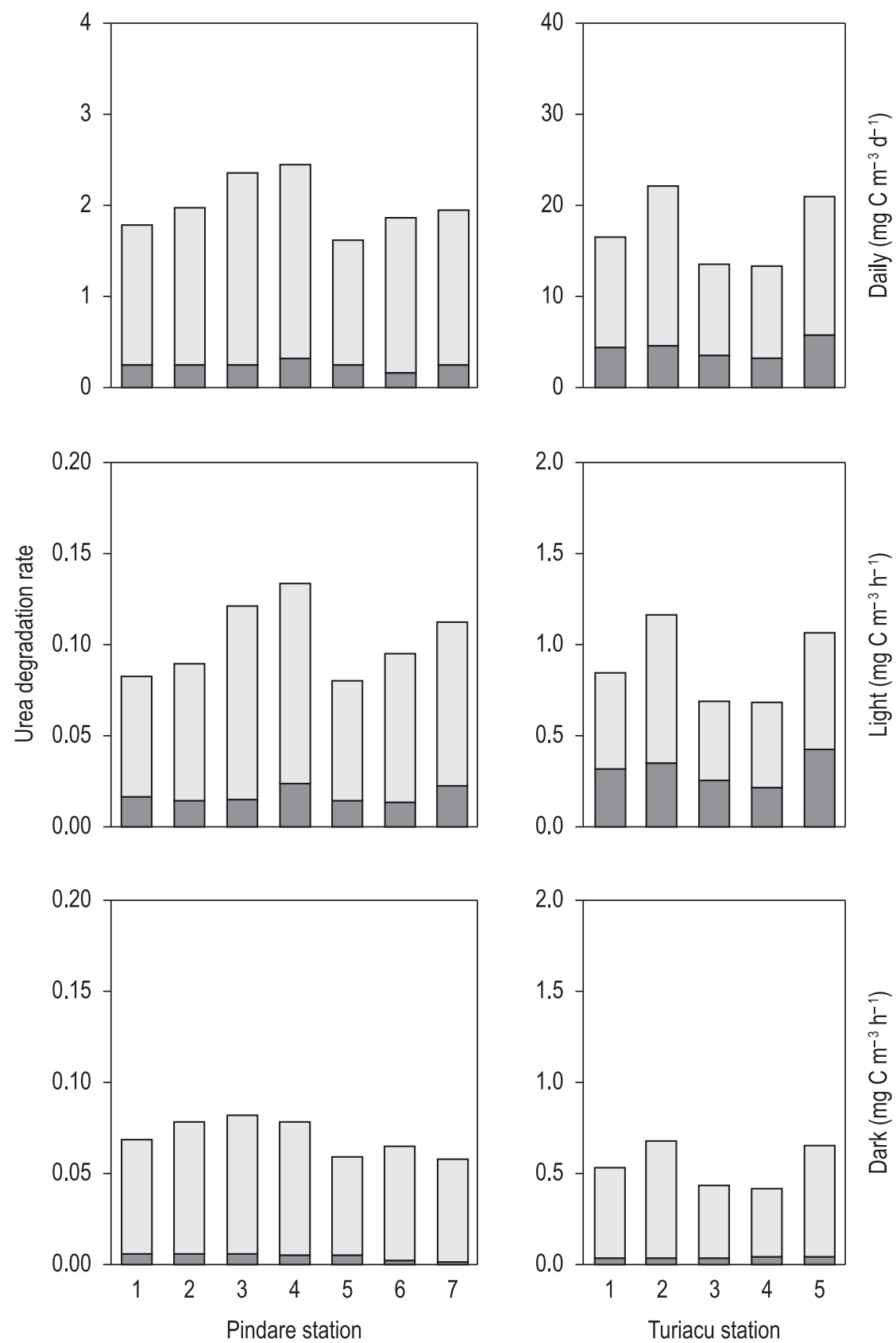

Figure 2. Distributions in degradation rates of urea (sum of rates in urea carbon incorporation into particulate matter and $\mathrm{CO}_{2}$ liberation into water originating in urea carbon) at the respective stations in the Pindaré and Turiaçu waters. Open and hatched columns indicate urea carbon incorporation rates and $\mathrm{CO}_{2}$ liberation rates, respectively. 
the Pindaré. The chlorophyll $a$ specific degradation rates in the Turiaçu proved to cover the same range as those reported by previous investigations in temperate and tropical lakes (Mitamura and Saijo, 1986a; Mitamura et al., 1995).

The distribution of the chlorophyll a specific urea degradation rate was somewhat similar to the pattern observed in photosynthetic activity (Figure 3). The ratio of the urea carbon degradation rate to the photosynthetic carbon assimilation rate in the Pindaré and Turiaçu systems was calculated to range, respectively, from 0.008 to 0.018 and 0.039 to 0.044 during the day. The contribution of carbon incorporation into cells (particulate matter) from urea was between 0.11 and $0.16 \%$ of the photosynthetic carbon assimilation in the Pindaré, i.e., between 0.90 and $1.18 \%$ in the Turiaçu. The current contributions of urea carbon to the carbon source of phytoplankton (particulate matter) were almost negligible.

To clarify the relationship between the urea degradation rate and the phytoplankton biomass or its photosynthetic rate, the regression equation of the urea degradation rate against the chlorophyll $a$ amount or photosynthetic rate was calculated by linear regression analysis. The linear regression equations of the urea degradation rate $(\mathrm{U}$; mg urea $\left.\mathrm{C} \mathrm{m}^{-3} \mathrm{day}^{-1}\right)$ against the chlorophyll $a$ amount $(\mathrm{C}$; $\mathrm{mg}$ chl. $a \mathrm{~m}^{-3}$ ) were: $\mathrm{U}=-0.001 \mathrm{C}+2.0, \mathrm{R}^{2}=0.01$, $\mathrm{p}<0.5$ in the Pindaré, and $\mathrm{U}=1.44 \mathrm{C}-12.6$, $\mathrm{R}^{2}=0.86, \mathrm{p}<0.05$ in the Turiaçu. The correlation coefficient between the urea degradation rate and photosynthetic rate showed a high value at a statistically significant level $\left(\mathrm{R}^{2}=0.98, \mathrm{p}<0.001\right)$ in the Turiaçu, in contrast to a low value in the Pindaré $\left(\mathrm{R}^{2}=0.03, \mathrm{p}<0.5\right)$.

\subsection{Cycling of urea in water}

The residence time of urea in water, supposing a steady state, can be expressed as the time necessary to degrade an amount of urea equivalent to the environment concentration. The residence time of urea was calculated from the daily urea degradation rate and urea concentration (Table 3). The residence time in surface water was calculated to be between 2.3 and 4.5 days in the Pindaré, and 0.21 and 0.50 days in the Turiaçu. There were no appreciable differences among the respective stations in the two aquatic systems. Much shorter residence times were obtained in the Turiaçu due to the rapid degradation rate of urea. Several studies have estimated the residence time for urea using ${ }^{14} \mathrm{C}$-labelled urea in freshwaters (Mitamura and Saijo, 1986a; Mitamura et al., 2000). The residence times in the current investigations were shorter than the values in freshwater lakes and reservoirs in temperate and tropical zones.

In the turbid water of the Pindaré and Turiaçu aquatic systems, urea was presumably degraded by phytoplankton. Although a small amount of urea carbon was incorporated into the phytoplankton cells, a good part of the carbon was liberated into the water as $\mathrm{CO}_{2}$ phase during the urea degradation. In the dark regime, in particular, the incorporation phase was a negligible contribution in the urea degradation. Several studies (Carpenter et al., 1972a; Irmisch, 1991; Mitamura et al., 1994, 2000; Tamminen and Irmisch, 1996) reported a negligible amount of carbon incorporation from degraded urea, findings that agreed with the tendency noted in the current results. The urea was better degraded in the light condition than in the

Table 2. Contribution of urea carbon incorporation rate $\left(\mathrm{C}\right.$ incorporation) and $\mathrm{CO}_{2}$ liberation rate from urea $\left(\mathrm{CO}_{2}\right.$ liberation) to the urea degradation rate (Degradation) during daily, light and dark regimes, and dark to light ratio of degradation, $\mathrm{C}$ incorporation and $\mathrm{CO}_{2}$ liberation in the Pindaré and Turiaçu aquatic systems.

\begin{tabular}{lcc}
\hline \multicolumn{1}{c}{ Parameter } & Pindaré station & Turiaçu station \\
\hline C incorporation/Degradation & & \\
Daily (\%) & $12(9-14)$ & $24(21-27)$ \\
Light (\%) & $17(13-20)$ & $35(30-39)$ \\
Dark (\%) & $7(3-10)$ & $7(5-11)$ \\
$\mathrm{CO}_{2}$ liberation/Degradation & & \\
Daily (\%) & $88(86-91)$ & $76(73-79)$ \\
Light (\%) & $83(80-87)$ & $65(61-70)$ \\
Dark (\%) & $93(90-97)$ & $93(89-95)$ \\
Dark/Light & & \\
Degradation & $0.70(0.51-0.88)$ & $0.62(0.59-0.64)$ \\
C incorporation & $0.28(0.08-0.41)$ & $0.13(0.10-0.21)$ \\
$\mathrm{CO}_{2}$ liberation & $0.77(0.62-0.97)$ & $0.88(0.62-0.96)$ \\
\hline
\end{tabular}



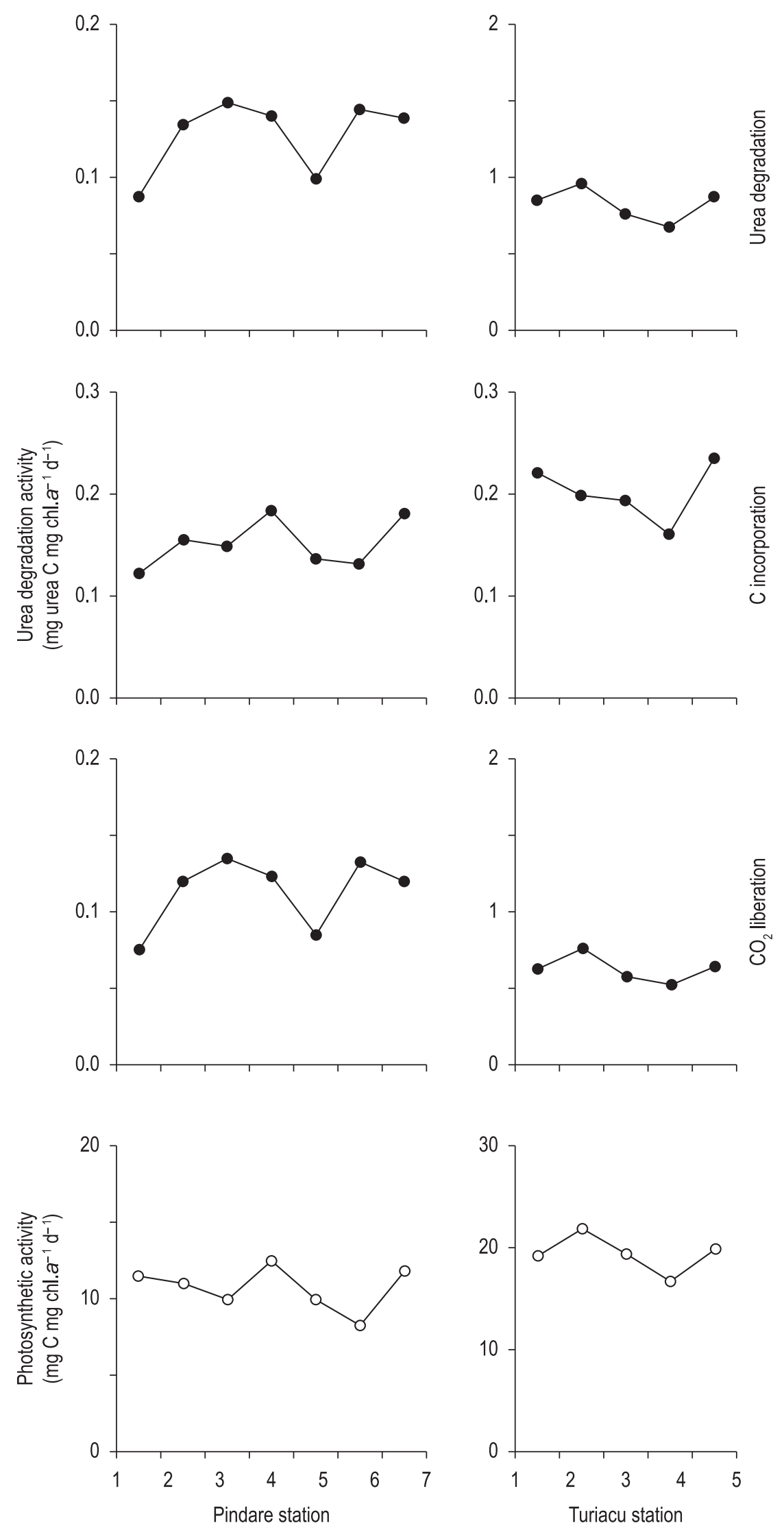

Figure 3. Distributions in urea degradation activity (specific urea degradation rate using chlorophyll $a$ as a cell parameter), and photosynthetic activity (photosynthetic rate per unit of chlorophyll $a$ amounts during one day) at respective stations in the Pindaré and Turiaçu waters. 
dark one. The current findings suggest that during the day urea degrades into the two phases of carbon incorporation and $\mathrm{CO}_{2}$ liberation, while during the night it degrades only into $\mathrm{CO}_{2}$ liberation. In the Pindaré and Turiaçu waters, the present ratios might increase with depth upon an attenuation of light intensity. The variation in the ratio of dark to light values might be partly caused by the differences in phytoplankton species, as suggested by Webb and Haas (1976), by the physiological condition of the microorganisms, as well as by their lower levels of irradiance due to turbid waters. Although, light intensity was not determined, the turbidity and the high suspended solids concentrations were in the same range as those in Solimóes river during the low water season according to previous studies by Mitamura et al. (2000) about grain size distribution of particulate matter and sediment. The irradiance, in the present aquatic systems, might be a key parameter affecting the dark to light ratio in urea degradation.

Urea degradation activity bears a close relationship to the utilization of urea nitrogen by phytoplankton, as suggested by Carpenter et al. (1972b) and Mitamura and Saijo (1986a). They also reported that the urea was mainly degraded during the urea nitrogen uptake by phytoplankton, and that, simultaneously, the urea carbon was assimilated by phytoplankton as a carbon source. The principal nitrogenous compounds which sustain the standing crop of phytoplankton populations in natural waters are thought to be urea, ammonia and nitrate, as reported in several studies (McCarthy et al., 1977; Mitamura and Saijo, 1986a; Presing et al., 2001; Twomey et al., 2005; Mitamura et al., 2006). In the current investigation, variations in the relationship between the urea degradation rate and the photosynthetic rate or the chlorophyll $a$ amount might be due to a difference in the contribution of urea nitrogen as a nitrogen source for phytoplankton growth. The strong relationship $\left(R^{2}=0.72, p<0.1\right)$ between the urea carbon incorporation rate and photosynthetic carbon assimilation rate was noted in light bottles from the Turiaçu, whereas a low value $\left(\mathrm{R}^{2}=0.25\right.$, $\mathrm{p}<0.5)$ was observed in the Pindaré. This suggests that the urea degradation rate was proportional to the standing crop of phytoplankton and its photosynthetic rate, and that the degradation may have been due to the autotrophs. In the Pindaré waters, a weak relationship might be due to a difference in the contribution of urea nitrogen as a nitrogen source for phytoplankton growth, as well as to the variations in bacterial degradation among respective stations in this aquatic system. This indicates that in the Turiaçu system an appreciable amount of urea degradation, particularly in the case of carbon incorporation into particulate matter, is associated with the photosynthesis of phytoplankton. Therefore, in the present results, the carbon incorporation into particulate matter in the urea degradation can be considered as due to the carbon uptake process into phytoplankton cells. The variation in the urea degradation rate might result in a difference in the utilizable activity of phytoplankton species and their physiological conditions, as noted by Fan et al. (2003), although such a variation must take into account the levels of the bacterial utilization for the urea degradation as described above.

Several investigators have reported that natural bacterial assemblages could utilize urea (Satoh and Hanya, 1976; Mitamura et al., 1994; Park et al., 1997; Joergensen, 2006). However, very little urea degrading activity occurs under natural conditions. This would suggest that the urea concentration in natural waters is below the critical level for bacterial utilization (Mitamura et al., 1994), or that the urease activity of bacteria is inhibited by the presence of ammonia (Magana-Plaza and RuizHerrera, 1967). The degradation of urea in natural waters occurs in connection with the photosynthesis of phytoplankton, as suggested by several studies using ${ }^{14} \mathrm{C}$-labelled urea (Mitamura and Saijo, 1975, 1986a; Webb and Haas, 1976; Mitamura et al., 2000). Mitamura et al. (1995) indicated that the urea in tropical lakes was degraded by phytoplankton

Table 3. Residence times and urea concentrations in waters at respective stations in the Pindaré and Turiaçu waters.

\begin{tabular}{lccc}
\hline $\begin{array}{c}\text { Aquatic } \\
\text { system }\end{array}$ & Station & $\begin{array}{c}\text { Urea } \\
(\mu \mathrm{M})\end{array}$ & $\begin{array}{c}\text { Residence time } \\
\text { (day) }\end{array}$ \\
\hline Pindaré & 1 & 0.66 & 4.5 \\
& 2 & 0.61 & 3.7 \\
& 3 & 0.51 & 2.6 \\
& 4 & 0.47 & 2.3 \\
& 5 & 0.36 & 2.7 \\
& 6 & 0.42 & 2.7 \\
Turiaçu & 7 & 0.39 & 2.4 \\
& & & \\
& 1 & 0.64 & 0.5 \\
& 2 & 0.40 & 0.2 \\
& 3 & 0.56 & 0.5 \\
& 4 & 0.30 & 0.3 \\
& 5 & 0.37 & 0.2 \\
\hline
\end{tabular}


rather than by bacteria during both dry and rainy seasons. Webb and Haas (1976) considered that urea degradation seemed to be an exception to the general rule of competition between phytoplankton and bacteria for the utilization of dissolved organic compounds. On the other hand, Mitamura et al. (1994) pointed out that the bacterial contribution to urea degradation was recognized in polluted river waters. In the pre-Amazonian floodplain, in terms of urea degradation, the phytoplankton in both the Turiaçu and Pindaré aquatic systems seemed to compete with bacteria. However, in both turbid waters, heterotrophic bacteria attached to the surface of suspended solids may also have contributed to urea degradation at the same time as autotrophic phytoplankton. Both the current and previous results imply that the utilization of urea by phytoplankton seems to be one of the important functions in the urea degradation of natural tropical waters, although its detailed physiological pathway remains obscure.

In the waters of both aquatic systems, a short residence time for urea cycling was observed. Mitamura and Saijo (1986b) suggested that the urea regeneration rate from excretion and mineralization is equivalent to their degradation rate, and that these processes are in a state of dynamic balance. The current brief residence time indicates that the urea was rapidly recycled in the euphotic zone of the tropical aquatic ecosystems in the pre-Amazonian floodplain.

In summary, the present findings indicate that in the aquatic systems of the pre-Amazonian floodplain of Baixada Maranhense, Brazil, the degradation of urea occurred in connection with the photosynthesis of phytoplankton, and that the urea might be more readily degraded by phytoplankton rather than by the bacteria with which phytoplankton compete, though the bacterial role in urea degradation remains obscure. To fully understand urea cycling in the pre-Amazonian floodplain, the total dynamics of urea in the water system, including the shading effect by high turbidity on urea degradation activity, ought to be carefully examined. Furthermore, the phytoplankton taxa and their structure, their physiological state and specific growth rate, and the allochthonous input of urea from their watersheds, as well as the bacterial contribution to urea degradation must be incorporated into further investigations as key parameters influencing urea cycling.

\section{Acknowledgements}

The authors wish to thank the following ongoing members of the cooperative study: the students J. P. Pontes, S. C. C. Santana and C. L. M. Serra. They also wish to express their gratitude for the financial support provided by the Japan International Cooperation Agency (JICA) to japanese scientists. Thanks are also due to Dr. M. Nakayama, Division of Natural Sciences, Osaka Kyoiku University, for his valuable advice in the use of radioactive carbon, and to the members of the Limnological Laboratory, University of Shiga Prefecture, for their generous assistance in the chemical analyses.

We thank Roler Ibañez for English final revision.

\section{References}

BARBIERI, R., IBAÑEZ, MSR., ARANHA, FJ., CORREIA, MMF., REID, JW. and TURNER, P. 1989. Plankton, primary production and some physico-chemical factors of two lakes from Baixada Maranhense. Revista Brasileira de Biologia, vol. 49, p. 399-408.

BENDSCHNEIDER, K. and ROBINSON, RJ. 1952. A new spectrophotometric method for the determination of nitrite in sea water. Journal of Marine Research, vol. 11, p. 87-96.

BOZELLI, RL. and GARRIDO, AV. 2000. Gradient of inorganic turbidity and responses of planktonic communities in an Amazonian lake, Brazil. Verhandlungen Internationale Vereinigung für Theoretische und Angewandte Limnologie, vol. 27, p. 147-151.

BRAY, GA. 1960. A simple efficient liquid scintillator for counting aqueous solutions in a liquid scintillation counter. Analytical Biochemistry, vol. 1, no. 4-5, p. 279-285. http://dx.doi.org/10.1016/00032697(60)90025-7

CARNEIRO, LS., BOZELLI, RL. and ESTEVES, FA. 2002. Long-term changes in the density of the copepod community in an Amazonian lake impacted by bauxite tailings. Amazoniana, vol. 17, p. 553-566.

CARPENTER, EJ., REMSEN, CC. and SCHROEDER, B. 1972a. Comparison of laboratory and in situ measurement of urea decomposition by a marine diatom. Journal of Experimental Marine Biology and Ecology, vol. 8, no. 3, p. 259-264. http://dx.doi. org/10.1016/0022-0981(72)90065-2

CARPENTER, EJ., REMSEN, CC. and WATSON, SW. 1972b. Utilization of urea by marine phytoplankters. Limnology and Oceanography, vol. 17, no. 2, p. 265-269.

CHANG, FH., BRADFORD-GRIECE, JM., VONCENT, WF. and WOODS, PH. 1995. Nitrogen uptake by the summer size-fractionated phytoplankton assemblages in the Westland, New 
Zealand, upwelling system. New Zealand Journal of Marine and Freshwater Research, vol. 29, p. 147-161.

CHO, BC. and AZAM, F. 1995. Urea decomposition by bacteria in the Southern California Bight and its implications for the mesopelagic nitrogen cycle. Marine Ecology Progress Series, vol. 122, p. 21-26. http://dx.doi.org/10.3354/meps122021

CHO, BC., PARK, MG., SHIM, JH. and AZAM, F. 1996. Significance of bacteria in urea dynamics in coastal surface waters. Marine Ecology Progress Series, vol. 142, p.19-26. http://dx.doi.org/10.3354/ meps 142019

DEVOL, AH., FORSBERG, BR., RICHEY, JE. and PIMENTEL, TP. 1995. Seasonal variation in chemical distributions in the Amazon (Solimóes) River: A multiyear time series. Global Biogeochemical Cycles, vol. 9, no. 3, p. 307-328. http://dx.doi. org/10.1029/95GB01145

EPPLEY, RW., CARLUCCI, FA., HOLM HANSEN, O., KIEFER, D., McCARTHY, JJ., VENRICK, E. and WILLIAMS, PM. 1971. Phytoplankton growth and composition in shipboard cultures supplied with nitrate, ammonium, or urea as the nitrogen source. Limnology and Oceanography, vol. 16, no. 5, p. 741-751.

FAN, C., GLIBERT, PM., ALEXANDER, J. and LOMAS, MW. 2003. Characterization of urease activity I three marine phytoplankton species, Aureococcus anophagefferens, Prorocentrum minimum, and Talassiosira weissflogi. Marine Biology, vol. 142, no. 5, p. 949-958.

FARJALLA, VF., ESTEVES, FA., BOZELLI, RL. and ROLAND, F. 2002. Nutrient limitation of bacterial production in clear water Amazonian ecosystem. Hydrobiologia, vol. 489, no. 1-2, p. 197-205. http:// dx.doi.org/10.1023/A:1023288922394

FISHER, TR., MORRISSEY, KM., CARLSON, PR., ALVES, L F. and MELACK, JM. 1988. Nitrate and ammonium uptake by plankton in an Amazon River floodplain lake. Journal of Plankton Research, vol. 10, no. 1, p. 7-29. http://dx.doi.org/10.1093/ plankt/10.1.7

FISHER, TR. and PARSLEY, PE. 1979. Amazon lakes: water storage and nutrient stripping by algae. Limnology and Oceanography, vol. 24, no. 3, p. 74-92. http://dx.doi.org/10.4319/lo.1979.24.3.0547

FORSBERG, BR., DEVOL, AH., RICHEY, JE., MARTINELLI, LA. and DOS SANTOS, A. 1988. Factors controlling nutrient concentrations in Amazon floodplain lakes. Limnology and Oceanography, vol. 33, no. 1, p. 41-56.

GU, BH., HAVENS, KE., SCHELSKE, CL. and ROSEN, BH. 1997. Uptake of dissolved nitrogen by phytoplankton in a eutrophic subtropical lake. Journal of Plankton Research, vol. 19, no. 6, p. 759-770. http://dx.doi.org/10.1093/plankt/19.6.759
GUENTHER, M. and BOZULL, R. 2004. Factors influencing algae-clay aggregation. Hydrobiologia, vol. 523, no. 1-3, p. 217-223. 10.1023/B:HY DR.0000033127.05034.32

HARRISON, WG., HEAD, EJH., CONOVER, RJ., LONGHURST, AR. and SAMEOTO, DD. 1985. The distribution and metabolism of urea in the eastern Canadian Arctic. Deep-Sea Research, vol. 32, no. 1, p. 23-42. http://dx.doi.org/10.1016/01980149(85)90015-9

HARVEY, WA. and CAPERON, J. 1976. The rate of utilization of urea, ammonium, and nitrate by natural populations of marine phytoplankton in an eutrophic environment. Pacific Science, vol. 30, no. 4 , p. 329-340.

HOLM-HANSEN, O., LORENZEN, CJ., HOLMES, RW. and STRICKLAND, JDH. 1965. Fluorometric determination of chlorophyll. Journal du conseil/ Conseil international pour l'exploration de la mer, vol. 30, no. 1, p. 3-15. http://dx.doi.org/10.1093/ icesjms/30.1.3

IBANEEZ, MSR. 1997. Phytoplankton composition and abundance of a central Amazonian floodplain lake. Hydrobiologia, vol. 362, no. 1-3, p. 79-83. http:// dx.doi.org/10.1023/A:1003124905996

IBAÑEZ, MSR., CAVALCANTE, PRS., COSTA NETO, JP., BARBIERI, R., PONTES, JP., SANTANA, SCC., SERRA, CLM., NAKAMOTO, N. and MITAMURA, O. 2000. Limnological characteristics of three aquatic system of the pre-amazonian floodplain, Baixada Maranhense (Maranhao, Brazil). Aquatic Ecosystem Health and Management, vol. 3, no. 4, p. 521-531. http://dx.doi. org/10.1016/S1463-4988(00)00048-8

IRMISCH, A. 1991. Investigations on the urea uptake by phytoplankton in the Baltic Sea. Acta Hydrochimica et Hydrobiologica, vol. 19, no. 1, p. 39-44. http:// dx.doi.org/10.1002/aheh.19910190106

JOERGENSEN, NOG. 2006. Uptake of urea by estuarine bacteria. Aquatic Microbial Ecology, vol. 42, no. 3, p. 227-242.

JUNK, WJ. and WEBER, GE. 1996. Amazonian floodplains: a limnological perspective. Verhandlungen des Internationalen Verein Limnogie, vol. 26, p. 149-157.

KRISTIANSEN, S. 1983. Urea as a nitrogen source for the phytoplankton in the Oslofjord. Marine Biology, vol. 74, no. 1, p. 17-24. http://dx.doi.org/10.1007/ BF00394270

MAGANA-PLAZA, I. and RUIZ-HERRERA, J. 1967. Mechanisms of regulation of urease biosynthesis in Proteus rettgeri. Journal of Bacteriology, vol. 93, no. 4, p. 1294-1301. PMid:6032508.

MARLIER, G. 1967. Ecological studies of some lakes of the Amazon Valley. Amazoniana, vol. 1, p. 91-115. 
McCARTHY, JJ. 1972. The uptake of urea by natural populations of marine phytoplankton. Limnology and Oceanography, vol. 17, no. 5, p. 738-748.

McCARTHY, JJ., TAYLOR, WR. and TAFT, JL. 1977. Nitrogenous nutrition of the plankton in Chesapeake Bay. I. Nutrient availability and plankton preferences. Limnology and Oceanography, vol. 22, no. 6, p. 996-1001.

MELACK, JM. and FISHER, TR. 1990. Comparative limnology of tropical floodplain lakes with an emphasis on the central Amazon. Acta Limnologica Brasiliensia, vol. 3, p. 1-48.

MITAMURA, O. 1986. Urea metabolism and its significance in the nitrogen cycle in the euphotic layer of Lake Biwa. II. Half-saturation constant for nitrogen assimilation by fractionated phytoplankton in different trophic areas. Archive für Hydrobiologie, vol. 107, p. 167-182.

MITAMURA, O. 1997. An improved method for the determination of nitrate in freshwaters based on hydrazinium reduction. Memoirs of Osaka Kyoiku University Series III, vol. 45, p. 297-303.

MITAMURA, O., CHO, KS. and HONG, SU. 1994. Urea decomposition associated with the activity of microorganisms in surface waters of the North Han River, Korea. Archive für Hydrobiologie, vol. 131, no. 1, p. 231-242.

MITAMURA, O., KAWASHIMA, M. and MAEDA, H. 2000. Urea decomposition by picophytoplankton in euphotic zone of Lake Biwa. Limnology, vol. 1, p. 19-26.

MITAMURA, O., MAEDA, H., SEIKE, Y., KONDO, K., GOTO, N. and KODAMA, T. 2006. Seasonal changes of carbon and nitrogen productivity in the north basin of Lake Biwa, Japan. Verhandlungen des Internationalen Verein Limnogie, vol. 29, p. 1913-1920.

MITAMURA, O., NAKAMOTO, N., IBAÑEZ, MSR.,COSTA NETO, JP. and BARBIERI, R. 2000. Grain Size distribution of particulate matter and sediment in extensive freshwater bodies in preAmazonian floodplain, Baixada Maranhense, Brazil. Verhandlungen des Internationalen Verein Limnogie, vol. 30, no. 6, p. 964-970.

MITAMURA, O. and SAIJO, Y. 1975. Decomposition of urea associated with photosynthesis of phytoplankton in coastal waters. Marine Biology, vol. 30, no. 1, p. 67-72. http://dx.doi.org/10.1007/BF00393754

MITAMURA, O. and SAIJO, Y. 1980. In situ measurement of the urea decomposition rates and its turnover rate in the Pacific Ocean. Marine Biology, vol. 58, no. 2, p. 147-152. http://dx.doi. org/10.1007/BF00396126

MITAMURA, O. and SAIJO, Y. 1981. Studies on the seasonal changes of dissolved organic carbon, nitrogen, phosphorus and urea concentration in Lake Biwa. Archive für Hydrobiologie, vol. 91, p. 1-14.

MITAMURA, O. and SAIJO, Y. 1986a. Urea metabolism and its significance in the nitrogen cycle in the euphotic layer of Lake Biwa. I. In situ measurement of nitrogen assimilation and urea decomposition. Archive für Hydrobiologie, vol. 107, p. 23-52.

MITAMURA, O. and SAIJO, Y. 1986b. Urea metabolism and its significance in the nitrogen cycle in the euphotic layer of Lake Biwa. IV. Regeneration of urea and ammonia. Archive für Hydrobiologie, vol. 107, p. $425-440$.

MITAMURA, O., SAIJO, Y. and HINO, K. 1995. Cycling of urea associated with photosynthetic activity of phytoplankton in the euphotic zone of tropical lakes, Brazil. Japanese Journal of Limnology, vol. 56, no. 2, p. 95-105.

MITAMURA, O., SAIJO, Y., HINO, K. and BARBOSA, FAR. 1995. The significance of regenerated nitrogen for phytoplankton productivity in the Rio Doce Valley Lakes, Brazil. Archive für Hydrobiologie, vol.134, no. 2, p. 179-194.

MURPHY, J. and RILEY, GA. 1962. A modified single solution method for the determination of phosphate in natural waters. Anaytica Chimica Acta, vol. 27, p. 31-36. http://dx.doi.org/10.1016/S00032670(00)88444-5

NEWELL, BS., MORGAN, B. and CUNDY, J. 1967. The determination of urea in seawater. Journal of Marine Research, vol. 25, p. 201-202.

PARK, MG., SHIM, JH. and CHO, BC. 1997. Urea decomposition activities in an enriched freshwater pond. Aquatic Microbial Ecology, vol. 13, p. 303-311. http://dx.doi.org/10.3354/ame013303

PRESING, M., VOROS, L., HERODEC, S. and ABRUSAN, G. 2001. Nitrogen uptake and the importance of internal nitrogen loading in Lake Balaton. Freshwater Biology, vol. 46, p. 125-139.

PRICE, NM. and HARRISON, PJ. 1988. Uptake of urea $\mathrm{C}$ and urea $\mathrm{N}$ by the coastal marine diatom Thalassiosira pseudonana. Limnology and Oceanography, vol. 33, no. 4, p. 528-537.

REDFIELD, AC. 1958. The biological control of chemical factors in the environment. American Scientist, vol. 46, no. 3, p. 205-221.

REID, JW. and TURNER, PN. 1988. Planktonic Rotifera, Copepoda and Cladocera from Lake Açu and Viana, State of Maranhão, Brazil. Revista Brasileira de Biologia, vol. 48, no. 3, p. 485-495.

REMSEN, CC., CARPENTER, EJ. and SCHROEDER, BW. 1972. Competition for urea among estuarine microorganisms. Ecology, vol. 53, p. 921-926.

RICHEY, JE., HEDGES, JI., DEVOL, AH., QUAY, PD., VICTORIA, R., MARTINELLI, L. and FORSBERG, BR. 1990. Biogeochemistry of carbon 
in the Amazon River. Limnology and Oceanography, vol. 35, no. 2, p. 352-371.

ROLAND, F., ESTEVES, FA. and BARBOSA, FAR. 2002. Relationship between antropogenically caused turbidity and phytoplankton production in a clear Amazonian floodplain lake. Amazoniana, vol. 17, p. 65-77.

SAGI, T. 1966. Determination of ammonia in seawater by the indophenol method and its application to the coastal and off-shore waters. The Oceanographical Magazine, vol. 18, p. 43-51.

SAIJO, Y., MITAMURA, O., HINO, K., IKUSIMA, I., TUNDISI, JG., MATSUMURA-TUNDISI, T., SUNAGA, T., NAKAMOTO, N. FUKUHARA, H., BARBOSA, FAR., HENRY, R. and SILVA, VP. 1997. Physicochemical features of rivers and lakes in Pantanal wetland. Japanese Journal of Limnology, vol. 58 , no. 1 , p. 69-82.

SATAKE, K., SAIJO, Y. and TOMINAGA, H. 1972. Determination of small quantities of carbon dioxide in natural waters. Japanese Journal of Limnology, vol. 33, p. 16-20.

SATOH, Y. and HANYA, T. 1976. Decomposition of urea by the larger particulate fraction and the free bacteria fraction in a pond water. Internationale Review gesamten Hydrobiologie, vol. 61, no. 6, p. 799-806. http://dx.doi.org/10.1002/iroh.19760610606

SATOH, Y., OKINO, T. and AOYAMA, K. 1980. Correlation between urea and other chemical and biological parameters in waters of Lake Suwa, Japan. Internationale Review gesamten Hydrobiologie, vol. 65, p. $445-454$.
SIOLI, H. 1984. The Amazon Limnology and land-scape ecology of a mighty tropical river and its basin. Dr. W. Junk Publishers.

STEEMANN NIELSEN, E. 1952. Use of radio active carbon $\left({ }^{14} \mathrm{C}\right)$ for measuring organic production in the sea. Journal du conseil/Conseil international pour l'exploration de la mer, vol. 18, p. 117-140.

TAGA, N. 1972. Occurrence of urea decomposing bacteria in the neritic and oceanic waters of the Northwest Pacific Ocean. In SUGAWARA, K., ed. The Kuroshio II. Tokyo: Saikon Pub. Co. Ltd. p. 341-356.

TAMMINEN, T. and IRMISCH, A. 1996. Urea uptake kinetics of a midsummer planktonic community on the SW coast of Finland. Marine Ecology Progress Series, vol. 130, p. 201-211. http://dx.doi. org/10.3354/meps130201

TWOMEY, LJ., PIEHLER, MF. and PAERL, HW. 2005. Phytoplankton uptake of ammonia, nitrate and urea in the Neuse River Estuary, NC, UAS. Hydrobiologia, vol. 533, no. 1-3, p. 123-134. http://dx.doi. org/10.1007/s10750-004-2403-z

WEBB, KL. and HAAS, LW. 1976. The significance of urea for phytoplankton nutrition in the York River, Virginia. In WILEY, M., ed. Estuarine processes. New York: Academic Press. vol.1, Uses, stresses, and adaptation to the estuary, p. 90-102.

ZOBELL, CE. and FELTHAM, CB. 1935. The occurrence and activity of urea splitting bacteria in the sea. Science, vol. 81, no. 2096, p. 234-236. http:// dx.doi.org/10.1126/science.81.2096.234

Received: 06 December 2011 Accepted: 22 August 2012 